УДК 347.129

DOI https://doi.org/10.32782/2409-4544/2019-2/15

H. Носік

\title{
Еволюція вчення про принципи цивільного права України
}

Стаття присвячена історико-правовому дослідженню еволюції вчення про принципи цивільного права і пошуку наукової та методологічної основи для подальшого розвитку, зміни $\mathrm{i}$ модернізації поглядів на основоположні ідеї цивільного права в цивілістичній доктрині України. Наукові положення про принципи цивільного права радянської доби є одночасно продуктом $\mathrm{i}$ заручником ідеологічних, політичних, правових, економічних та соціальних умов, в яких вони сформувалися та публікувалися. Задля подолання бар'єру цензури справжня цивілістична теорія в працях радянських правників нерідко виражалась у формулюваннях, свідомо перенасичених термінологією та реквізитами пануючої ідеології. Разом із цим, доктринальні дослідження принципів цивільного права, здійснені радянськими вченими-правниками, склали теоретичну, а також методологічну основу для подальшого опрацювання проблематики принципів цивільного права в цивілістиці України, виробленню нових поглядів на неї, і є одним із джерел, що формують витоки сучасної наукової правової думки. Сучасний стан розробки проблематики принципів цивільного права в Україні містить спадковість деяких підходів радянських правознавців і пов'язаний із результатами їх досліджень. Разом із тим, виникли сильні відмінності в поглядах на принципи цивільного права, в порівнянні 3 попереднім дискурсом у дослідження цієї теми. Найпомітніші відмінності виявляються, серед іншого, у відході від формального позитивізму у напрямку ідей природного права, універсальних цінностей, які лежать в основі невід'ємних прав людини, і до базових концепцій приватного права. Відзначено, що саме на принципах цивільного права повинні бути оновлені основні засади цивільного законодавства під час рекодифікаціі цивільного законодавства України.

Ключові слова: принципи цивільного права, наука, вчення, дослідження, доктринальні джерела.

Постановка наукової проблеми та її значення. Розвиток цивільного права України підтримує незмінну актуальність наукового дослідження його принципів. Невпинне вивчення та подальше осмислення концептуальних положень та ідей, що становлять основу цивільного права, відіграє ключову роль не лише в контексті сучасних процесів пан'європейської гармонізації правових систем, але й у розбудові національної системи цивільного права. Зокрема, саме на принципах цивільного права мають оновлюватись основні засади цивільного законодавства під час рекодифікації цивільного законодавства України, розпочатої згідно з Постановою Кабінету Міністрів України від 17 липня 2019 р. № 650 «Про утворення робочої групи щодо рекодифікації (оновлення) цивільного законодавства України».

Аналіз досліджень цієї проблеми. В сучасній ци вілістиці України вчення про принципи цивільного права $\epsilon$ досить розвинутим. Проблематиці принципів цивільного права України присвятили свої наукові праці, зокрема, О.В.Басай, С. М. Бервено, Т. В. Боднар, В. І. Борисова, Н. Ю. Голубєва, О. В. Дзера, І. А. Діковська, Р. А. Майданик, Н. С. Кузнєцова, О. В. Кохановська, О. О. Мережко, С. О. Погрібний, С. П. Рабинович, С. О. Харитонов, С. І. Шимон та інші українські вчені, істотно піднявши ступінь наукової розробки цієї теми у порівнянні з тим станом, в якому вона була успадкована від радянської науки цивільного права. Разом 3 тим очевидно, що саме доробок радянських вчених С. І. Вільнянського, О. С. Іоффе, С. М. Братуся, В. П. Грибанова, Н. А. Чечіної, О. О. Красавчікова, В. Ф. Маслова, Г. А. Свєрдлика та ін. у дослідженні принципів цивільного права став науковою і методологічною основою для подальшого розвитку, зміни і модернізації поглядів на основоположні ідеї цивільного права в цивілістичній доктрині України. Не дивлячись на це, малодослідженими залишаються еволюція наукових поглядів на принципи цивільного права, а також питання про роль, значення і зв'язок доробку радянської правової доктрини з сучасним вченням про принципи цивільного права України.

(๑) Носік Ю., 2019 
Формулювання мети та завдань статті. Ця стаття присвячена огляду основних положень про принципи цивільного права, вироблених радянськими цивілістами, виявленню зв'язків із сучасними поглядами та з'ясуванню їх значення для науки цивільного права України.

Виклад основного матеріалу й обгрунтування отриманих результатів дослідження. Серед перших комплексних праць у СРСР про радянське цивільне право, де, зокрема, були проаналізовані його принципи, слід назвати підручник для юридичних шкіл «Радянське цивільне право» [1], написаний в Українському науково-дослідному інституті юридичних наук під редакцією С. І. Вільнянського у 1940 році.

Використовуючи метод протиставлення основоположних ідей радянського цивільного права «буржуазному» цивільному праву С. І. Вільнянський виводить такі принципи: 1) закріплення соціалістичної системи господарства та соціалістичної власності на засоби виробництва; 2) охорона i захист права особистої власності громадян на їх трудові доходи та предмети споживання; 3) спрямування господарського життя СРСР народногосподарським планом; 4) поєднання особистих та суспільних інтересів; 5) забезпечення та гарантування прав радянських громадян; 6) забезпечення нерозривного зв'язку цивільних прав та обов'язків.

О. С. Іоффе, висвітлюючи принципи радянського цивільного права, зазначав, що «приницпи - те, на що спирається радянське цивільне право, що становить його основні начала» [2, с. 24]. Автор наводив такі ознаки принципів радянського цивільного права: а) вони $є$ всезагальними для галузі цивільного права, тобто пронизують не окремі, а всі норми та інститути галузі, б) закріплені в законодавстві, отримавши таким чином вияв у юридичних нормах, та в) $є$ специфічним (галузевим) виразом більш загального принципу, притаманного всьому радянському праву.

До числа принципів радянського цивільного права О. С. Іоффе зараховує такі принципи: 1) рівноправність суб'єктів цивільного права, цивільні відносини яких будуються як відносини юридичної рівності; 2) поєднання прав і обов'язків, що сприяє узгодженню суспільних та особистих інтересів; 3) принцип реальності та гарантованості цивільних прав; 4) принцип плановості, який відображає в собі уклад економіки держави; 5) принцип особистої ініціативи (індивідуальної або колективної) як основу розгортання економічних процесів; 6) принцип соціалістичної законності як найважливіший принцип радянського права.

С. М. Братусь у праці «Предмет та система радянського цивільного права» навів збірний перелік принципів радянського права, які зустрічались в навчальній літературі того часу. Серед них: «рівність громадян, яка трактується і як їх економічна рівність, і як рівноправність; поєднання прав і обов’язків у їх носіїв при соціалізмі, принцип соціалістичної законності; свобода особистості в соціалістичному суспільстві, обумовлена відміною приватної власності на знаряддя і засоби виробництва та ліквідацією експлуатації людини людиною; поєднання суспільних та особистих інтересів при соціалізмі; реальна забезпеченість в СРСР цивільних прав; соціалістичне планування чи плановість, якій підкорене цивільно-правове регулювання майнових відносин; соціалістична власність і соціалістична система господарства; договір як метод поєднання плану і госпрозрахунку та як форма вияву ініціативи та самостійності учасників майнових відносин; закон вартості та госпрозрахунок як його вияв у зв'язку з тим, що цивільне право регулює насамперед товарно-грошові відносини; принцип винагороди в міру праці» [3, с. 134].

Критично ставлячись до такого «конгломерату» принципів С. М. Братусь писав, що не можна погодитися 3 тим, що основними принципами радянського цивільного права $€$ і економічні закони, i різноманітні риси та сторони соціалістичних виробничих та інших відносин, і юридичні інститути, i юридичні категорії [3, с. 136]. 3 таким баченням узгоджується також твердження В. М. Семенова, який зазначав, що «не можна принципи інших різновидів суспільного життя автоматично вважати принципами права і навпаки» [4, с. 23].

Методологічно базуючись на засадах юридичного позитивізму С. М. Братусь запропонував певний спосіб виявлення галузевих принципів права: «... основні принципи якої-небудь галузі права ми маємо виявити в самих нормах, які становлять у сукупності дану галузь; якщо ж там принципи прямо не сформовані, вони мають бути виявлені з загальної суті норм» [3, с. 137]. Принагідно слід зауважити, що виведення принципів права із законодавства на сучасному етапі грунтовно критикує проф. М. І. Козюбра: «...поширені уявлення про те, що принципи права можна вивести з системи законодавства за допомогою логіко-формального аналізу його норм. Це не що інше як ілюзія, породжена започаткованим юридичним позитивізмом надмірним раціоналізмом у підходах до розуміння природи принципів права, як і права загалом. Насправді ніякий логічний зміст законодавства не здатний дати більше того, що в ньому закладено» [5, с. 145]. 
На основі власного дослідження С. М. Братусь вважав основними принципами радянського цивільного права такі: здійснення цивільних прав у відповідності з їх соціальним призначенням; поєднання суспільних та особистих інтересів; демократичний централізм, який конкретизується в принципах планової дисципліни, оперативної та майнової самостійності господарських організацій, договірних відносин та договірної дисципліни; рівноправність і добросовісність у здійсненні прав та виконанні обов'язків у відповідності до правил соціалістичного співжиття [3, с. 143].

Функції правових принципів (принципів системи радянського права, окремих його галузей чи інститутів) розкрив В.П. Грибанов, зазначивши, що вони: «...по-перше, виражають соціалістичну сутність радянського права; по-друге, визначають характер тлумачення i застосування норм соціалістичного права; по-третє, забезпечують вирішення справ, що виникають 3 відносин, не врегульованих нормами права; i, наостанок, по-четверте, правові принципи мають величезне виховне значення, відіграють важливу роль у формуванні соціалістичної правосвідомості трудящих» [6, c. 214]. В. П. Грибанов підкреслив, що правові принципи володіють значно більшою стабільністю, ніж норми права, становлять основний зміст галузі чи інституту права, i їх регулівна дія $є$ ширшою та не вичерпується лише регулюванням поведінки учасників правовідносин. Правові принципи, зазначає автор, - це керівні положення соціалістичного права, його основні начала, що виражають об'єктивні закономірності, тенденції та потреби суспільства, які визначають суть всієї системи, галузі чи інституту права та які мають в силу їх правового закріплення загальнообов' язкове значення.

Надавши загальну характеристику правовим принципам у їх об’єктивному розумінні, В. П. Грибанов одним з перших у радянській цивілістиці поставив питання про принципи цивільних прав у їх суб'єктивному значенні, тобто «принципи здійснення цивільних прав». Така постановка питань про принципи в цивільному праві піднімає цілий пласт нових і малодосліджених проблем, які мають безпосередній зв'язок із сучасними завданнями юридичної доктрини України. Це підтверджує проф. Є. О. Харитонов, зазначаючи, що принципи суб' єктивних цивільних прав заслуговують на те, щоб бути предметом спеціального грунтовного дослідження [7, с. 54].

В. П. Грибанов підтримує думку Н. А. Чечіної в тому, що принципи здійснення цивільних прав - це ті основні вимоги, які соціалістичне суспільство і виражаюче його інтереси радянське цивільне право висувають до управомоченої особи та тих осіб, які від іiі імені здійснюють належні управомоченій суб'єктивні цивільні права [6, с. 255].

Найважливішим принципом здійснення цивільних прав, на переконання Грибанова В.П., $є$ принцип соціалістичної законності. Важливе значення також мають принцип добросовісності, принцип здійснення цивільних прав у відповідності з їх призначенням, принцип реального здійснення цивільних прав, принцип товариської співпраці при здійсненні цивільних прав і обов'язків та принцип економічності [6, с. 225-231].

Слід навести підходи й інших радянських цивілістів до визначення поняття принципів цивільного права. О. О. Красавчіков правовими принципами називає певні начала, керівні ідеї, у відповідності з якими здійснюється правове регулювання суспільних відносин [8, с. 26-27]. Це одна 3 найбільш нейтральних дефініцій щодо пануючої ідеологічної риторики того часу, яка змінила $\mathrm{i}$ заклала оновлений підхід до формулювання вираження наукових поглядів на принципи цивільного права в пізню радянську добу.

Принципи радянського цивільного права - пропонує своє визначення Г. А. Свєрдлик - це закріплені або відображені в преамбулах основоположних нормативних актів, а також в цивільноправових нормах та виражаючі об'єктивні закономірності розвитку майнових та пов'язаних з ними особистих немайнових відносин, стабільні нормативно-керівні положення, у відповідності до яких вибудовується нормативна база цивільно-правового регулювання, регламентація поведінки суб'єктів цивільного права та правозастосування [9, с. 80].

Висновки. На завершення огляду основних підходів радянських цивілістів до принципів цивільного права слід зазначити наступне. Наукові положення про принципи цивільного права радянської доби $\epsilon$ одночасно продуктом i заручником ідеологічних, політичних, правових, економічних та соціальних умов, в яких вони сформувалися та публікувалися. Як слушно зазначає А. М. Колодій, «принципи права - історичні, це означає, що немає вічних і незмінних принципів $\mathrm{i}$ кожний тип права має свої принципи» [10, с. 15].

Задля подолання бар'єру цензури справжня цивілістична матерія в працях радянських правників нерідко виражалась у формулюваннях, свідомо перенасичених термінологією та реквізитами пануючої ідеології. Застосування умовного «фільтру» до всього «соціалістичного», «радянського», «комуністичного», «буржуазного», «народного», «трудящого» і т.ін. під час опрацювання наукових джерел радянської доби розкриває цінний зміст праць і вишуканий геній їх 
окремих авторів. Примітним у цьому контексті $є$ прийом О.С. Іоффе, який у праці «Радянське цивільне право» [2, с. 30-34] після опису принципів радянського цивільного права здійснив стриману критику принципів «буржуазного» приватного права, що дозволило приховано просочитись ідеям природного приватного права в опубліковану радянську юридичну літературу - i це було sapienti sat. Абстрагуючись, такі ідеї можна було почерпнути і з більш агресивної критики, наприклад, за авторства Д. М. Гєнкіна в загальній характеристиці буржуазного цивільного права [11, с. 33-40]. Принагідно слід зауважити, що автори тих праць, які становлять джерельну базу цієї статті, були дуже точні у термінах, називаючи предмет свого викладу не принципи цивільного права, а «принципи радянського цивільного права», що має важливе значення для правильного сприйняття суті їхньої наукової спадщини.

Сучасний стан розробки проблем принципів цивільного права в Україні, хоч і має риси наступництва та зв'язку з результатами досліджень радянських правників, виявляє разючі зміни у поглядах на досліджуваний об'єкт, порівнюючи з радянським дискурсом теми. Найпомітніші відмінності виявляються, 3-поміж іншого, у відході від формального позитивізму та спрямуванні поглядів до ідей природного права, універсальних цінностей, що лежать в основі невід'ємних прав людини, та до базових концепцій приватного права. Це відбувається в умах кардинальної зміни політичних, правових, економічних та інших обставин, котрі характеризують зміну цивілізаційного виміру, атмосфера якого зробила можливим на законодавчому рівні засудження в Україні комуністичного тоталітарного режиму 1917-1991 років.

Тим не менше, необхідно констатувати, що доктринальні дослідження принципів цивільного права, здійснені радянськими вченими-правниками, безвідносно до ідеологічного «акваріуму» свого часу, склали теоретичну, а також методологічну основу для подальшого опрацювання проблематики принципів цивільного права в цивілістиці України, виробленню нових поглядів на неї, і $є$ одним із джерел, що формують витоки сучасної наукової правової думки. Навіть сьогодні відкидати радянський спадок у розробці даної проблематики неможливо, адже окремі тези та положення 3 оглянутих видань знаходять свій відголосок в сучасних працях вчених і мають безпосереднє значення для триваючої дискусії про суть і роль принципів цивільного права.

\section{Джерела та література}

1. Советское гражданское право: Учебник для юридических школ: Допущен Управлением учебными заведениями НКЮ СССР в качестве учебника для стационарных и заочных юридических школ и курсовой сети НКЮ УССР / Украинский научно-исследовательский институт юридических наук; Под редакцией С. И. Вильнянского. - М.: Юридическое издательство НКЮ СССР, 1940. - 264 с.

2. Иоффе О. С. Советское гражданское право / О. С. Иоффе. - М.: Юридическая литература, 1967. $494 \mathrm{c}$.

3. Братусь С. Н. Предмет и система советского гражданского права / С. Н. Братусь. - М.: Госюриздат, 1963. - 198 с. - (Курс советского гражданского права / Всесоюзный институт юридических наук).

4. Семенов В. М. Конституционные принципы гражданского судопроизводства / В. М. Семенов. - М.: Юрид.лит., 1982. - 150 с.

5. Козюбра М. Принципи права: методологічні підходи до розуміння природи та класифікації в умовах сучасних глобалізаційних трансформацій / М. Козюбра // Право України, 2017. - № 11. C. $142-164$.

6. Грибачов В П. Осуществление и защита гражданских прав. Изд. 2-е, стереотип. / В. П. Грибанов. М.: Статут, 2001. - 411 с. (Классика российской цивилистики).

7. Цивільне законодавство України (основні категорії, принципи та концепти): монографія / авт. кол.; за заг. ред. Є. О. Харитонова. - Одеса: Фенікс, 2012. - 344 с.

8. Советское гражданское право: учебник. В 2-х томах. Т. 1/ Т. И. Илларионова, М. Я. Кириллова, О. А. Красавчиков и др.: Под ред. О. А. Красавчикова. - 3-е изд., испр. и доп. - М.: Высш. шк., 1985. - 544c.

9. Свердлик Г. А. Принципы советского гражданского права. Дис. ... докт. юрид. наук: 12.00.03 / Г. А. Свердлик. - Свердловск, 1985. - 428 с.

10. Колодій А. М. Принципи права України / А. М. Колодій. - Київ: Юрінком Інтер, 1998. - 207 с.

11. Советское гражданское право. Том I / Проф. Д. М. Генкин, проф. С. Н. Братусь, проф. Л. А. Лунц, проф. И. Б. Новицкий; Под редакцией проф. Д. М. Генкина; Всесоюзный институт юридических наук Министерства юстиции СССР. - М.: Государственное издательство юридической литературы, 1950. $496 \mathrm{c.}$ 
Носик Ю. Эволюция учения о принципах гражданского права Украины. Статья посвящена историко-правовому исследованию эволюции учения о принципах гражданского права и поиску научной и методологической основы для дальнейшего развития, изменения и модернизации взглядов на основополагающие идеи гражданского права в цивилистической доктрине Украины. Научные положения о принципах гражданского права советского времени является одновременно продуктом и заложником идеологических, политических, правовых, экономических и социальных условий, в которых они сформировались и публиковались. Для преодоления барьера цензуры настоящая цивилистическая теория в трудах советских юристов нередко выражалась в формулировках, сознательно перенасыщенных терминологией и реквизитами господствующей идеологии. Вместе с тем, доктринальные исследования принципов гражданского права, осуществленные советскими учеными-юристами, составили теоретическую, а также методологическую основу для дальнейшей разработки проблематики принципов гражданского права в цивилистике Украины, выработке новых взглядов на нее, и является одним из источников, формирующих истоки современной научной правовой мысли. Современное состояние разработки проблем принципов гражданского права в Украине, хоть и владеет чертами наследственности и связи с результатами исследований, в частности, советских правоведов, проявляет сильные отличия во взглядах на исследуемый объект, в сравнении с предыдущим дискурсом темы. Самые заметные отличия проявляются, среди другого, в отходе от формального позитивизма и направлению взглядов к идеям природного права, универсальных ценностей, которые лежат в основе неотъемлемых прав человека, и к базовым концепциям частного права. Отмечено, что именно на принципах гражданского права должны быть обновлены основные засады гражданского законодательства во время рекодификации гражданского законодательства Украины.

Ключевые слова: принципы гражданского права, наука, учение, исследование, доктринальные источники.

Nosik Yu. Evolution of the Doctrine of the Civil Law Principles in Ukraine. The article is devoted to the historical and legal study of the doctrine of the principles of civil law evolution and the search for a scientific and methodological basis for its further development, change, and modernization of views on the fundamental provisions of civil law in the civilistic doctrine of Ukraine. Scientific provisions about principles of civil law of the Soviet era are both a product and a hostage of the ideological, political, legal, economic and social conditions in which they were formed and published. For overcoming the barrier of censorship, the real civilist matter in the works of Soviet lawyers was often expressed in formulations deliberately oversaturated with terminology and details of the dominant ideology. At the same time, doctrinal researches of the principles of civil law, conducted by Soviet legal scholars, provided a theoretical and methodological basis for further studing of these principles in the civil law of Ukraine, the development of new views on it, and is one of the sources that form the origins of modern scientific legal thought.The current state of development of the issue of the civil law principles in Ukraine, although it has features of heredity and relevance to the research findings of the Soviet jurists, demonstrates essential differences in the views on the object under study, as compared to the previous discourse of the study. The most noticeable differences are manifested in the departure from formal positivism towards the ideas of natural law, the universal values that underlie inalienable human rights, and to the basic concepts of private law. The author argues that it is on the principles of civil law that the basic principles of law should be updated during the recodification of the civil law of Ukraine.

Key words: principles of civil law, science, doctrine, research, doctrinal sources. 